\title{
自然再生に対する地域住民の意識構造に関する研究 滋賀県近江八幡市西の湖を対象として
}

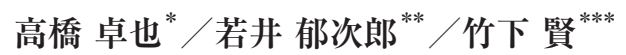

\begin{abstract}
要 旨
琵琶湖に残存する希少な内湖で、近江八幡市にある西の湖を自然再生の一つの研究事例として 選定した。そして、自然再生ガバナンスの有効な実施プロセスづくりや、将来継承を見通す合意 形成には、多様なステークホルダーの一員である、内湖社会圈の地域住民の意識構造が重要な要 素になると考え、2011年にフォーカス・グループ・インタビュー調査および地域住民 327 名を対 象としたアンケート調查を実施した。分析結果より、将来の西の湖シナリオに対する意見の違いは、 「伝統回帰環境志向」「観光地志向」「地元公園志向」の 3 つの軸に集約できることが分かった。 また、西の湖に対して回答者が抱く将来シナリオは、回答者の職業との間に相関があることも確 認された。地域住民は、将来シナリオ「魚のゆりかごとしての西の湖」を共有概念とするガバナン スの下で自然再生にむけた合意形成に協力しうることが示唆された。

キーワード : 滋賀県、琵琶湖内湖、自然再生、内湖社会圈、合意形成
\end{abstract}

\section{I はじめに}

自然再生に対する国民の関心の高まりを受け、2002年 12 月、自然再生推進法が制定、2003年 1 月より施行された。 これに基づく自然再生の実効的な推進には、同法で位置付 けられている自然再生協議会が中心的役割を果たしており、 2012 年 3 月現在、全国で 24 の自然再生協議会が設置、26 件の自然再生事業実施計画が策定されている(環境省、 2012)。

同法では「自然再生」を「過去に損なわれた自然環境を取 り戻すため、関係行政機関、関係地方公共団体、地域住民、 NPO、専門家等の地域の多様な主体が参加して、自然環境 の保全、再生、創出等を行うこと」(同法第二条) と定義し ているように、地域の多様な主体の参加が期待されている ことが特徴に挙げられる(則久、2003)。しかし、同法は、新 たな規制や財源措置が伴わないため、実効性を高めるには、 ボトムアップ形式の事業として実施しなければならない。

実際、次節で概観するように、先行研究においても、か つての自然への再生課題として、多様な主体の間の協働、 ガバナンス、合意形成が挙げられ、それらに重点をおいた 研究がなされてきた。特に合意形成の視点より先行研究を 見ると、自然度の高い地域における自然再生事業の構想や、 実施中の事業を対象として合意形成の事後分析を行ってい るが、合意形成における地域住民の意識構造の分析と解釈 を試みた研究は見当たらない。

そこで、本研究では、自然再生事業を構想する以前の段 階にあって、地域住民の意識構造の分析と解釈に着目し、

* 滋賀県立大学 $/ * * 大$ 大阪産業大学 $/ * * *$ 関西大学
大都市圈に比べ地元地域への関心や期待が強い中小都市域 での自然再生に対する地域住民の態度の分布や構成、態度 と住民特性の相関関係を分析し、地域住民の意識構造を解 明することを目的とする。特に、住民の職業が自然環境の 将来シナリオ (将来像) 評価に与える影響に焦点を当てて分 析を行う。

なお、本研究は自然再生推進法に該当する自然再生事業 を扱うものではないが、ここでは同法を手がかりとして、 以下、自然再生の意義を検討する。

\section{II 先行研究}

\section{1 概念整理亡総論的研究}

前出の自然再生推進法第二条による「自然再生」の定義 によれば、再生によって取り戻す対象は「過去に損なわれ た自然環境」であるが、本研究が対象とする「西の湖」とい う内湖に関わる事業が、同法にいう「自然再生」に相当す るのかどうかを問うとき、前提となる先行研究の領域はか なり広範囲にわたることになる。

問題となるのは、西の湖が「過去に損なわれた自然環境」 であるのかどうか、ということである。西の湖は残存した 内湖であって、対象となる事業は再生ではなく、むしろ維 持ないし保全である。とはいえ、法律上もこうした自然再 生事業から保全事業を排除することは適切ではない。実際、 自然再生推進法第一条は「生物の多様性の確保を通じて自 然と共生する社会の実現を」目的として規定している。

こうした自然環境の保全事業の重要性は、先行研究を参 照することによってより明らかになる。勢一(2009)は自然 再生推進法を素材として「協働型政策決定」を行政法の視 
点から、協働のメカニズムの理論化が「ガバナンス論、パー トナーシップ論、コモンズ論、社会関係資本論」といった 一般理論のレベルで、学際的に進められていると分析して いる。こうした学際的な取り組みについて、それぞれの立 場を概観していて有益なのは井上(2008)である。そこでは コモンズ論を基礎に独自の主張として「協治」の概念が提 示され、協治の対象であるコモンズには、「自然資源の共 同管理制度、および共同管理の対象である資源そのもの」 という定義が与えられている。

このように、自然環境ないし自然資源との持続的な共生 をめざすとすれば、その管理は協働であるか協治であるか はともあれ、自然再生推進法第二条も規定するように「地 域の多様な主体が参加」する体制を必要としている。そう した体制について、社会的共通資本論からも(宇沢・茂木、 1994) ガバナンス論からも (菅・三俣・井上、2010) 研究が 行われている。

\section{2 先行実証研究}

多くの先行実証研究は、既往の自然再生事業の経過を解 明し、いかに事業を促進できるかという問題意識をもって 分析している。これらの実証研究を分析の着目点より整理 すると、(1)自然再生事業に対する意識調査 (支払い意志額 の推定を含む)、(2)ローカル・ガバナンスの特徴分析、(3) 合意形成の構造と機能分析、(4)体制づくりの特徴分析、(5) 活動の拡大・成長の要因分析、の5類型に大別することが できる。

(1)自然再生事業に対する意識調查 (支払い意志額の推定 を含む)としては、伊尾木·阿波根·中山(2006)、高(2009)、 柴・桜井 (2005) がある。伊尾木・阿波根・中山は、特定の 里山環境に扔ける、自然再生・管理活動に対するイベント 参加者および地域住民の意識について調査を行っている。 高は、韓国の NPO と専門家を対象として、整備事業およ び官民協働に対する意識がNPO と専門家の間でどのよう に異なるかを探った。柴・桜井は、現在実施中の自然再生 事業に対する地域住民の支払い意志額を推定している。

(2)ローカル・ガバナンスの特徴分析としては、新藤 (2007) がある。新藤は、全国の再生事業の先駆けともいえる、釧 路湿原に打ける自然再生事業を、多様な主体が参加する ローカル・ガバナンス (共治) と見なして、その特徴を分析 している。

(3)合意形成の構造と機能分析としては、高橋(2007)、勢 一(2009)、千葉(2007)がある。高橋は、三番瀬干潟の埋め 立てから自然再生への政策転換における三番瀬再生計画検 討会議(円卓会議) 等の合意形成の場 (アリーナ)の変遷に着 目し、行政、市民運動、漁業者等の間の対立関係、相互作 用、協働関係を明らかにしている。そのうえで、アリーナ に抒けるファシリテーターの重要性を指摘している。勢一 は、自然再生推進法に基づく自然再生事業を協働型政策決
定として捉え、その仕組みと課題について全国の事例から 行政法の視点より幅広く論じている。千葉は、釧路湿原に おける再生事業に対して消極的な農業者・観光業者、そし て積極的な NPO ・官庁・研究者の対立関係を分析している。 (4)体制づくりの特徴分析としては、阿波根・中山(2005)、 高塚・進士 (2009) の研究がある。阿波根・中山は 3 件の事 例から、自然再生事業に扔けるイメージ像拈よび目標設定、 地域で共通の目的をめざし事業を推進するための体制づく りについてそれぞれ特徴の把握を試みている。高塚・進士 (2009)では、田園自然再生コンクールへの平成 $15 １ 8$ 年 度の応募票 207 件を分析し、活動開始のきっかけ、活動 内容、対象とする生物種などについて俯瞰的把握を試み ている。

(5)活動の拡大要因分析としては、高塚・西塚・進士 (2009)、長谷川 (2008)がある。高塚・西塚・進士は、田園 自然再生コンクールの 2003 年度から 2007 年度の受賞 33 団 体を対象としてアンケート調查を実施し、活動の拡大・発 展の状況抄よびその要因を解明した。長谷川は、環境社会 学の視点から、兵庫県のコウノトリ野生復帰プロジェクト および群馬県赤谷プロジェクトの成長・発展・成功の要因 を検討し、政治的機会構造、人的資源やメディアの支援、 シンボル的なフレームの創出といった要因を挙げている。

以上の諸研究のうちで、特に本研究の視点から興味深い のは、新藤(2007) および勢一(2009)である。新藤は、行政 への不信からローカル・ガバナンスに参加をしない住民が 存在することと、諸個人の労働と生活が主体間の関係、さ らにはローカル・ガバナンスを規定していることを指摘し ている。勢一は、協議会への参加が各主体の自発性に委ね られているため、地域住民抄よびその他の主体の参加は保 障されたものではないことから、参加の確保ひいては協議 会の運営に支障が生じる事例があることを指摘している。

これらの指摘にある自然再生への地域住民の不参加の背 景を再考すると、コモンズあるいは自然資本として地域社 会が共有している自然環境を自立的に再生するには、間接 的な参加の意識醸成や、利害調整の事前情報収集を視野に 入れ、多様な生活・環境観をもつ地域住民の意識調査を行 い、その意識構造を捉え、地域住民の意識を反映できる合 意形成が重要であると考えられる。

しかし、こうした研究アプローチは、これまでの先行研 究では十分ではなかったことをふまえ、本研究では、滋賀 県近江八幡市の西の湖周辺地域を対象として、自然再生に 対する地域住民の意識構造を分析する。

\section{III 研究対象地とその概要}

\section{1 研究対象地の選定}

本研究は、これまで大きな改変や改造の経緯がなく、自 然環境の質的向上をめざし日常的に維持されている営為を 含む広義の自然再生を範囲として、一定のまとまりある地 
域社会が共有している固有の自然環境の再生に向けて、継 続的に取り組んできている地域住民の意識構造の解明をね らいとしている。筆者らが研究フィールドとしている中か ら、このような条件におおむね適合する研究対象地として、 滋賀県の近江八幡市に位置する西の湖周辺を選定した(図 1 参照)。

選定の主な理由は、(1)地域住民の少なくとも一部に自然 再生への強い期待感があること、(2)中小都市域に位置し、 人々の生活と深く関わった自然であり、特有の課題の存在 が予想されること、(3)体系立った自然再生事業が開始され ておらず、人々が自然再生事業に関わる情報に対して特別 に意識していない、素直な状態であること、の 3 点である。

\section{2 西の湖の概要}

琵琶湖は、2010年において約 $670 \mathrm{~km}^{2}$ の面積をもち、滋 賀県の約 $17 \%$ 占めている日本最大の湖である。琵琶湖 周辺の湖岸陸側に内湖と呼ばれる小湖沼が多数存在してい たが、かつて40以上あった内湖は、戦後の食糧増産など を目的に約半数が干拓された。西の湖は、干拓されずに残っ た希少な内湖のひとつであり(株式会社ラーゴ、2010)、残 存している内湖のうち最大の面積 $2.22 \mathrm{~km}^{2}$ を有し、平均水 深は約 $1.5 \mathrm{~m}$ である。ヨシ原の面積は $1.09 \mathrm{~km}^{2}$ に達し、琵琶 湖の内湖のヨシ原全体の半分以上を占めている。

西の湖は、湖、河川、水草带、ヨシ原、ヤナギ林、農耕地、 周囲の里山が入り混じる自然環境の豊かなところであり、 西の湖およびその周辺は独特の生物的多様性を有している (株式会社ラーゴ、2010)。とりわけ、ヨシ原を利用する動 植物、水期遺存種とされる寒地性植物、自然の営力による 攪乱に依存する原野性植物、水鳥、琵琶湖水系固有種魚類 が重要であると考えられている。

1993年、琵琶湖はラムサール条約に登録され、2008年 には西の湖も拡大登録を受けた(ラムサール条約登録湿地 関係市町村会議、2012)。

西の湖固有の湿地生態系は、古来、人の生活と深く関わ
り、水産業や農業はもとより、伝統的ヨシ産業や淡水真珠 養殖業の地場産業を育成してきた。ヨシについていえば、 ヨシ産業が必要とする良質なヨシの育成には、「ヨシ地焼 き」が不可欠である。この営為は、ヨシ地の植生維持だけ でなく、湿地生態系の形成維持に結びついて、ヨシ地が創 りだす自然景観と文化景観にも貢献している。たとえば、 ヨシ産業による「ヨシ地焼き」はヨシ地の植生維持に結び ついている。こうした関わりにより形成された景観が評価 され、2006年、西の湖を含む「近江八幡の水郷」は、国の 重要文化的景観の第1号に選定された(文化庁、2012; 近 江八幡市、2011)。

\section{3 内湖社会圏の概要}

西の湖という内湖が形成している自然環境を中心にして 生活や産業が営まれるなかで、伝統行事や習慣、共同作業 などの諸活動が継承され、これらが西の湖の水量・水質の 水環境や、藻類、魚類などの水生生物、水草などの生態系 の保全に直接・間接に結びついている地域社会を、ここで は内湖社会圈と呼ぶことにする。この研究においては、具 体的に西の湖に面する 6 町丁が湖岸を連続して取り囲む社 会空間としている(図 1 参照)。

内湖社会圈の規模は、近江八幡市の面積 $101 \mathrm{~km}^{2}$ の約 $17 \% 、 17 \mathrm{~km}^{2}$ (総務省、2005)、人口は 81,700 人の $11 \%$ 弱、 8,800 人(総務省、2012)である。

内湖社会圈は、前述したように西の湖の水域環境と里山 と農村集落が織り成す水郷景観を形成している地域社会で ある。現在も、伝統行事や習慣などがよく継承されている だけでなく、地域社会外の人々を積極的に迎え入れ、西の 湖の保全意識を高揚させるイベント開催や清掃美化の活動 などを行うなど、進取の気風にも富んでいる。

この研究では、これらの背景を考慮し、内湖社会圈のな かでも西の湖に対して定期的に地域活動を活発に行ってい る町丁の自治会の協力を得て、地域住民の意識構造を解明 するため、次のフォーカス・グループ・インタビューおよ
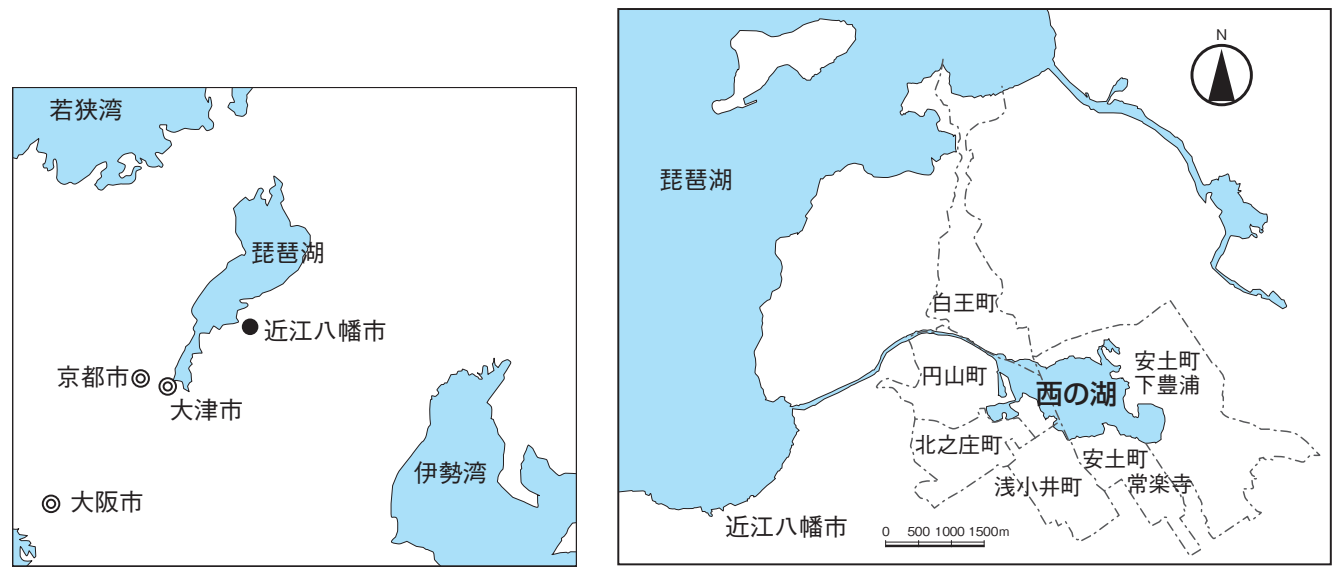

図 1 近江八幡市の位置と西の湖・内湖社会圏 
びアンケート調査を実施することにした。

\section{IV 調查研究の方法}

本研究では、西の湖と共生するうえで、地域住民が自然 環境の保全や再生に、いかに関わってきたか、という問題 意識をもって、統計資料などの資料収集ならびに現地フィー ルドワークを実施しながら、西の湖の自然地理や歴史的変 遷、自然環境や生態系の現状と保全活動、内湖社会圈の社会経済・環境に関わる諸活動などの予備的情報を収集した。

これらの予備的情報を背景に、地域住民の意識構造を解 明することをめざし、フォーカス・グループ・インタビュー およびアンケート調查を実施した。

まず、フォーカス・グループ・インタビューは、聞き手 がもっている西の湖の自然環境や地域社会活動に関わる問 題意識に基ついて、具体的な内容を社会的知識と経験の豊 かな地域住民に問いかけ、当該の地域住民より回答を聞き 取る方法である。本研究では、西の湖の環境保全に意欲的 に関わっている人、自治活動に活発に携わっている人、西 の湖と直接・間接に関わり生業としている人たちの協力を 得て、実施した。

アンケート調查は、予備的情報やフォーカス・グループ. インタビューの結果をふまえ、回答者の属性を問うフェイ スシートと、西の湖の自然再生に関連する質問項目から構 成した。そして、回答者が自然再生に関わる質問内容とし て「西の湖との関わり」「西の湖での環境保全活動」「西 の湖への夢(ビジョン)」「西の湖再生への道筋」「行政か らの支援の現状」「行政への要望」に自由回答を含め 7 区 分し、これらに対して、容易に理解でき回答しやすいよう、 複数選択式回答または 5 段階評価からの択一式回答を求め るアンケート設計を行い、実施した。回収したアンケート結 果は、単純集計、平均や分散など基本統計量に基ついて相関 分析、因子分析、数量化理論 I 類などの多変量解析を行い、 得られた結果に対して解积や意味付けを与元、西の湖の自 然再生に対する地域住民の意識の特徵を明らかにした。

なお、本論文は、地域住民の意識構造の分析に重点をお いているため、後述する「V 3 アンケート調查に基づく 地域住民の意識分析」では、アンケート調査結果のうち、分 析に直接関連するデータと主要結果のみ揭載している。

\section{$\mathrm{V}$ 分析および考察}

\section{1 インタビュ一調査の概要}

フォーカス・グループ・インタビューは、地元の精通者 を通じて、特に西の湖の環境問題に関心のある人々の参加 協力を得て、下記の要領で実施した。

(1)調査実施日：2011 年 4 月 16 日（土）

(2)調 查 場 所 : 近江八幡市白王町

(3)実施協力者：12 名 (西の湖周辺の 3 町丁、白王、円山、 および北之庄在住の地域住民）
2 インタビュ一調査に基づく地域住民の意識分析

フォーカス・グループ・インタビューでは、概括的には 次のような意見が確認された。

年配者にとっては、西の湖と関わった農業、漁業、ヨシ (蔁) 地管理の思い出がある。とりわけ、西の湖の泥藻を肥 料として利用し、西の湖のなかの農地との行き来に舟を使 う農業の姿は独特であった。シジ、、イケチョウガイなど の貝、スッポンの卵を採ったり、野鬼をとらえたりするな どの思い出もある。

周辺の内湖の干拓工事、水路 - 堤防の建設以降、以上の ような密接な内湖との関係はやや疎遠になってきている。

現在、西の湖およびその周辺の環境を保全するため、ご み拾いなどのボランテイア活動が行われており、県外から の参加者もいる。ヨシ刚り、ヨシ地焼き(ヨシの再生のため の野焼き)のボランティア活動もなされている。西の湖中 の小島(「権座」と呼ばれる)での農業維持のため、営農組合 がイベント開催などもして地域外からの参加者の力も取り 入れつつ活動を行っている。

西の湖に対しては、水質面での改善を評価する声もある 一方、以前と比較して現状に不満もある。生物多様性の面 では、在来魚の減少抢よび外来魚の増加に関心が寄せられ ている。景観面では、西の湖のなかほどにある真珠養殖施 設の残骸のほかには、大きな不満は聞かれなかった。

今後の西の湖のあり方については、湖流の改善、魚の放 流による水質の改善、ヨシ地の管理方法の改善、周辺里山 環境と合わせた保全、などさまざまな意見が存在する。そ の背後には、たとえば在来魚の減少の原因として、外来魚 の増加、乱獲などさまざまな要因が考えられて抢り、因果 関倸の想定が多様であり、かつ各人の西の湖環境への着目 点がそれぞれ異なっていることが考えらえる。

以上の意見は、次に述べるアンケート調査に取り入れた。

\section{3 アンケート調査に基づく地域住民の意識分析}

\section{（1）アンケート調査の概要}

アンケート調查は、上述したフォーカス・グループ・イ ンタビューに狲て、妥当性を確認したうえで、アンケー 卜調査項目を確定し、回答者の男女比や年齢層などについ てバランスよい回答を得ることに配慮して、下記の要領で 実施した。

(1)調査実施日：2011年5月15日(日)および22日(日)

(2)調 査 対 象：西の湖周辺の白王、円山抢よび北之庄の 3 町の 271 世带

(3)配布・回収: 各戸 2 部配布・留置き。 1 週間後に回収 または郵送

(4)配 布 数: 542 票

(5)回 収 数: 327 票

(6)回 収 率: $60 \%$

なお、一部の町内自治会で協力が得られたところでは、 
表 1 回答者の年齢と職業のクロス構成

\begin{tabular}{|c|c|c|c|c|c|c|c|c|c|c|c|c|c|}
\hline 属 性 & $\begin{array}{l}\text { 会 } \\
\text { 社 } \\
\text { 員 }\end{array}$ & $\begin{array}{l}\text { 公 } \\
\text { 務 } \\
\text { 貝 }\end{array}$ & $\begin{array}{l}\text { 農 } \\
\text { 善 } \\
\text { 徰 } \\
\text { 者 }\end{array}$ & 主 & $\begin{array}{l}\text { 漁 } \\
\text { 晝 } \\
\text { 者 }\end{array}$ & & & $\begin{array}{l}\text { 観 } \\
\text { 光 } \\
\text { 遊 } \\
\text { 船 }\end{array}$ & $\begin{array}{l}\text { そ } \\
\text { 他 }\end{array}$ & $\begin{array}{l}\text { 畣 } \\
\text { 全 }\end{array}$ & $\begin{array}{l}\text { 構 } \\
\text { 成 } \\
\stackrel{2}{\%} \\
\%\end{array}$ & $\underset{p}{z}$ & $\begin{array}{l}\text { 回 } \\
\text { 䇧 } \\
\text { 数 } \\
\text { 犬 }\end{array}$ \\
\hline 20 代 & 6 & 2 & & 1 & & & 2 & & & 11 & 4 & & 11 \\
\hline 30 代 & 12 & & & 9 & & 1 & & & 1 & 23 & 8 & & 23 \\
\hline 40代 & 14 & 2 & 2 & 11 & & & & & 4 & 33 & 11 & & 33 \\
\hline 50 代 & 29 & 3 & 1 & 27 & 1 & 1 & & 1 & 6 & 69 & 24 & 4 & 73 \\
\hline 60 代 & 18 & & 15 & 37 & 2 & 4 & & 1 & 29 & 106 & 36 & 11 & 117 \\
\hline 70 代 & 1 & & 9 & 13 & 1 & 2 & & & 13 & 39 & 13 & 7 & 46 \\
\hline 80 代以上 & & & 2 & 4 & & & & & 5 & 11 & 4 & 3 & 14 \\
\hline 合計 (人) & 80 & 7 & 29 & 102 & 4 & 8 & 2 & 2 & 58 & 292 & 100 & 25 & 417 \\
\hline 構成比（\%) & 27 & 2 & 10 & 35 & 1 & 3 & 1 & 1 & 20 & 100 & - & - & - \\
\hline N.A. & 1 & & 1 & 1 & & & & & & 3 & - & 7 & 10 \\
\hline 回答者数 (人) & 81 & 7 & 30 & 103 & 4 & 8 & 2 & 2 & 58 & 295 & - & 32 & 327 \\
\hline
\end{tabular}

表2 居住経験

\begin{tabular}{lcc}
\hline 居住経験 & 回答者 $($ 人) & 構成比 $(\%)$ \\
\hline 生まれてからずっと同じ集落に住んでいる & 184 & 63 \\
21 年以上前に移住してきた & 79 & 27 \\
$11 \sim 20$ 年前に移住してきた & 21 & 7 \\
$0 \sim 10$ 年前に移住してきた & 10 & 3 \\
\hline 合計 & 294 & 100 \\
\hline N.A. & 33 & \\
\hline 回答者計 & 327 & \\
\hline
\end{tabular}

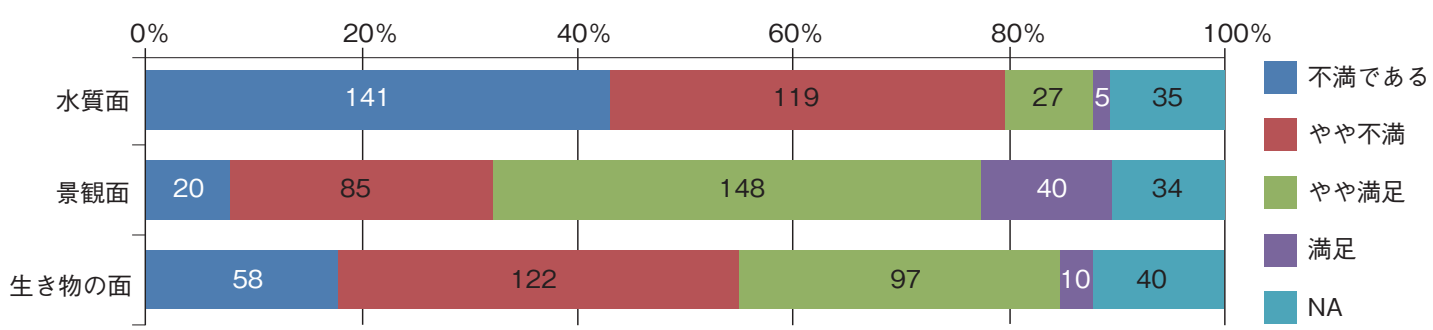

図 2 西の湖に対する評価 $(n=327)$

地元住民の代表が各戸配布・回収を行った。

(2) 回答者の特性

回答数は 315 名(無回答を含むと 327 名)であり、うち男 性が 168 名で $53 \%$ 、女性が 147 名で $47 \%$ であり、回答者の 男女比は、おおむね同等である ${ }^{1)}$ 。

回答者の年齢構成は、20代から 80 代までの各年齢層か ら回答が得られているが、60代が全体の約 4 割、60代以 上で過半数 $(53 \%)$ と、全体として高齢者の回答が多くなっ ている(表 1 参照) ${ }^{2)}$ 。

回答者の職業でみると、主婦が最も多く35\%、次いで会 社員が $27 \%$ となっている。また、農業従事者が $10 \%$ であり、 主婦、会社員および農業従事者からの回答で全体の 7 割超 を占めている(表 1 参照)。

居住経験についてみると、現在の地域で生まれて住んで いる回答者は 6 割と最も多い。21年以上前に移住してき た回答者を含めると、9割となり、現在地での暮らしが長
い回答者が多数を占めている (表 2 参照)。

現在の西の湖に対して水質面、景観面および生き物の 面の三つの側面から、どのように評価するかをたずねた。 水質面および生き物の面では、「不満である」、「やや不満」 と回答した人数は、それぞれ 260 名、180名である。他方、 景観面では「満足」、「やや満足」と回答した人数は 188 名で ある。このように現在の西の湖は、水質面や生き物の面 では不満、景観面では満足という評価になっている(図 2 参照)。

西の湖への夢(ビジョン)をたずねるため、下記の6つの 将来シナリオを地域住民に提示して、それぞれの望ましさ について回答をしてもらった。

・魚のゆりかごとしての西の湖

- 訪問型観光地としての西の湖

・滞在型観光地としての西の湖

・地域の公園としての西の湖 


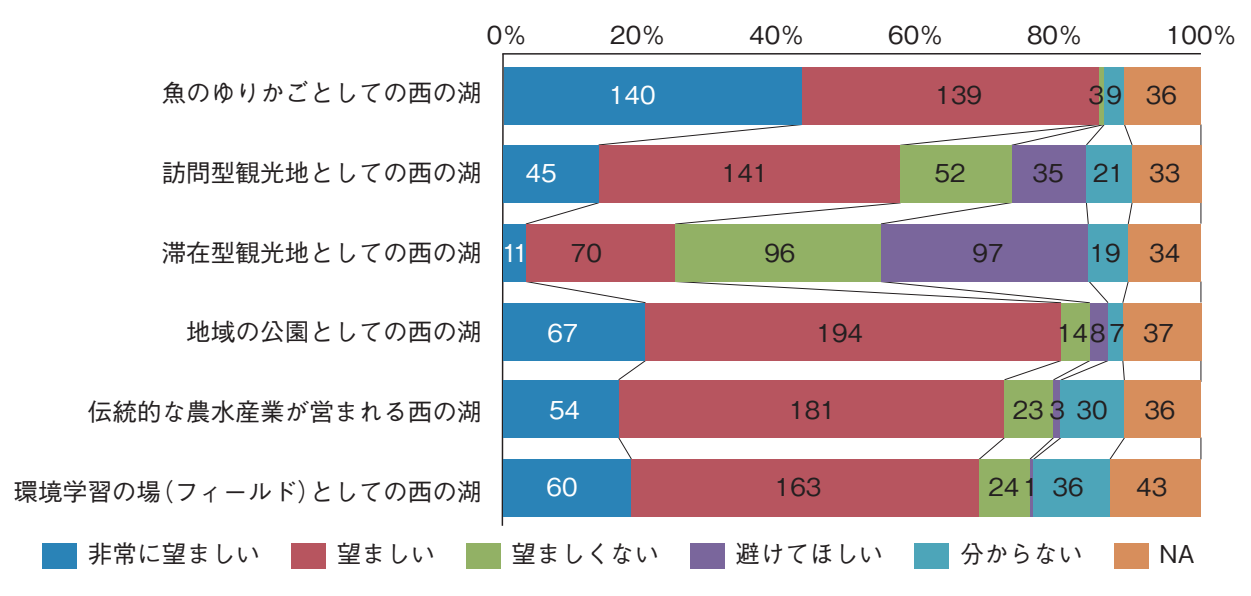

図3西の湖の将来シナリオ $(n=327)$

表 3 西の湖将来シナリオ評価值の相関係数行列

\begin{tabular}{|c|c|c|c|c|c|c|}
\hline & $\begin{array}{l}\text { 魚 } \\
の \\
ゆ \\
\text { り } \\
\text { か } \\
\text { ご }\end{array}$ & $\begin{array}{l}\text { 訪 } \\
\text { 閵 } \\
\text { 䇾 } \\
\text { 光 } \\
\text { 地 }\end{array}$ & $\begin{array}{l}\text { 滞 } \\
\text { 在 } \\
\text { 型 } \\
\text { 観 } \\
\text { 党 } \\
\text { 地 }\end{array}$ & $\begin{array}{l}\text { 地 } \\
\text { 域 } \\
\text { 公 } \\
\text { 園 }\end{array}$ & $\begin{array}{l}\text { が伝 } \\
\text { 営統 } \\
\text { 的 } \\
\text { れな } \\
\text { る農 } \\
\text { 西水 } \\
\text { 産 } \\
\text { 湖業 }\end{array}$ & 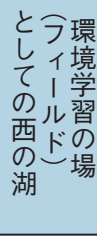 \\
\hline 魚のゆりかごとしての西の湖 & 1 & 0.174 & 0.123 & 0.229 & 0.228 & 0.291 \\
\hline 訪問型観光地としての西の湖 & 0.174 & 1 & 0.423 & 0.289 & 0.155 & 0.229 \\
\hline 滞在型観光地としての西の湖 & 0.123 & 0.423 & 1 & 0.303 & 0.097 & 0.174 \\
\hline 地域の公園としての西の湖 & 0.229 & 0.289 & 0.303 & 1 & 0.092 & 0.251 \\
\hline 伝統的な農水産業が営まれる西の湖 & 0.228 & 0.155 & 0.097 & 0.092 & 1 & 0.537 \\
\hline 環境学習の場 (フィールド) としての西の湖 & 0.291 & 0.229 & 0.174 & 0.251 & 0.537 & 1 \\
\hline
\end{tabular}

\section{・伝統的な農水産業が営まれる西の湖}

\section{・環境学習の場 (フィールド) としての西の湖}

3 番目のシナリオ (滞在型観光地としての西の湖) を除く 5つのシナリオに対して「非常に望ましい」、「望ましい」 とする回答数が、「望ましくない」「避けてほしい」とする 回答数を上回っている。これら 5 つシナリオが多くの住 民に期待されている西の湖の未来のビジョンであることが 分かる(図 3 参照)。

\section{（3）西の湖に対する将来シナリオ評価の因子分析}

つぎに、西の湖の将来シナリオの評価全体に潜在してい る共通性を明らかにするため、評価を点数化(高評価を高 得点)し、因子分析を行うことにした(奥野ほか、1974)。こ の分析結果に対応するシナリオ評価変数相互の相関係数を 表 3 に示す。

因子分析は、 3 因子、 4 因子、 5 因子と段階的に増やし 試行したところ、3 因子の場合においてのみ、いずれの因 子においても 0.5 以上の因子負荷量が現われた。このため 最も少ない因子数によって、単純で明快な説明ができる、 3 因子による説明を採用した。スクリープロットによる分 析からも、固有值のてい減(逈減) 傾向の分岐点となる 3 因 子が適切であると考えられた。

この分析過程を経て、表 4 の結果が得られ、因子分析の
結果、抽出された因子の解勫は、次のようになる。

因子 1 を構成する主な変数は、「伝統的な農水産業が営 まれる西の湖」と「環境学習の場(フィールド)としての西の 湖」であり、この因子を「伝統回帰環境志向」と命名する。

同様に、因子 2 を構成する主な変数は、「滞在型観光地 としての西の湖」と「訪問型観光地としての西の湖」であり、 この因子を「観光地志向」と命名する。

因子 3 は「地域の公園としての西の湖」の 1 変数であり、 この因子を「地元公園志向」と命名する。

残りの変数「魚のゆりかごとしての西の湖」は、因子よ りうける影響は小さい。この理由は、先に見たように、西 の湖の将来シナリオ「魚のゆりかごとしての西の湖」は、他 の 5 つのナリオに比べて「望ましい」との回答を多数得 ていることからも分かるように、5つのシナリオを包括す る中立的なイメージとして理解され、回答されたことにあ ると推測される。

\section{(4) 将来シナリオの要因分析}

つぎに、西の湖の将来シナリオの評価に影響を与えてい る要因を明らかにするため、多面的に相関分析を行うこと にした。

そこで、シナリオ評価を目的変数とし、各回答者の基礎 情報 (集落、年齢、性別、職業、居住歴)を説明変数として、 
表 4 西の湖の将来シナリオ各々の評価に基づく因子分析結果

\begin{tabular}{lccc}
\hline 因子 & 因子1 & 因子2 & 因子3 \\
\hline 因子名 & 伝統回帰環境志向 & 観光地志向 & 地元公園志向 \\
\hline 伝統的な農水産業が営まれる西の湖 & $\underline{0.774}$ & 0.071 & 0.032 \\
\hline 環境学習の場(フィールド)としての西の湖 & $\underline{0.668}$ & 0.134 & 0.297 \\
\hline 帯在型観光地としての西の湖 & 0.052 & $\underline{0.711}$ & 0.143 \\
訪問型観光地としての西の湖 & 0.142 & $\underline{0.538}$ & 0.219 \\
地域の公園としての西の湖 & 0.069 & 0.307 & 0.545 \\
魚のゆりかごとしての西の湖 & 0.271 & 0.096 & 0.334 \\
\hline 寄与率(\%) & 19.11 & 15.37 & 9.44 \\
\hline
\end{tabular}

注 1 ) 因子負荷量はバリマックス回転後の数值。

2) 0.5 以上の因子負荷量について下線を加えた。

表5 基礎情報アイテムと西の湖シナリオ評価の間の相関関係 (数量化理論 I 類のレンジ值の大小により順位付け)

\begin{tabular}{|c|c|c|c|c|c|c|c|c|c|c|c|c|}
\hline $\begin{array}{l}\text { 基礎情報 } \\
\text { アイテム }\end{array}$ & \multicolumn{2}{|c|}{$\begin{array}{c}\text { 魚の } \\
\text { ゆかご }\end{array}$} & \multicolumn{2}{|c|}{$\begin{array}{l}\text { 訪問型 } \\
\text { 観光地 }\end{array}$} & \multicolumn{2}{|c|}{$\begin{array}{l}\text { 㴆在型 } \\
\text { 観光地 }\end{array}$} & \multicolumn{2}{|c|}{ 地域の公園 } & \multicolumn{2}{|c|}{$\begin{array}{c}\text { 伝統的 } \\
\text { 農水産業 }\end{array}$} & \multicolumn{2}{|c|}{ 環境学習の場 } \\
\hline 集落 & 0.131 & 5位 & 0.340 & 4位 & 0.374 & 5位 & 0.077 & 4位 & 0.276 & 3位 & 0.178 & 5位 \\
\hline 年齢 & 0.200 & 3位 & 1.126 & 2位 & 0.977 & 2位 & 0.621 & 2位 & 0.323 & 2位 & 0.635 & 2位 \\
\hline 性別 & 0.238 & 2位 & 0.195 & 5位 & 0.473 & 3位 & 0.065 & 5位 & 0.240 & 5位 & 0.193 & 4位 \\
\hline 職業 & 1.202 & 1 位 & 1.440 & 1 位 & 1.424 & 1 位 & 1.234 & 1 位 & 1.357 & 1 位 & 1.506 & 1 位 \\
\hline 居住歴 & 0.153 & 4位 & 0.350 & 3位 & 0.465 & 4位 & 0.111 & 3位 & 0.269 & 4位 & 0.246 & 3位 \\
\hline $\begin{array}{l}\text { 決定 } \\
\text { 係数 }\end{array}$ & \multicolumn{2}{|c|}{0.105} & \multicolumn{2}{|c|}{0.132} & \multicolumn{2}{|c|}{0.132} & \multicolumn{2}{|c|}{0.094} & \multicolumn{2}{|c|}{0.125} & \multicolumn{2}{|c|}{0.153} \\
\hline
\end{tabular}

表 6 西の湖の将来シナリオ評価に関する職業別カテゴリースコア（数量化理論 I 類）

\begin{tabular}{|c|c|c|c|c|c|c|c|}
\hline アイテム & カテゴリー & $\begin{array}{c}\text { 魚の } \\
\text { ゆかご }\end{array}$ & $\begin{array}{l}\text { 訪問型 } \\
\text { 観光地 }\end{array}$ & $\begin{array}{l}\text { 滞在型 } \\
\text { 観光地 }\end{array}$ & $\begin{array}{l}\text { 地域の } \\
\text { 公園 }\end{array}$ & $\begin{array}{c}\text { 伝統的 } \\
\text { 農水産業 }\end{array}$ & 環境学習の場 \\
\hline \multirow{9}{*}{ 職業 } & 1 会社員 & -0.04 & -0.02 & 0.07 & -0.03 & 0.02 & -0.03 \\
\hline & 2 公務員 & $\underline{\underline{0.26}}$ & 0.08 & -0.40 & 0.16 & $\underline{\underline{0.29}}$ & $\underline{\underline{0.30}}$ \\
\hline & 3 農業従事者 & -0.23 & $\underline{\underline{0.29}}$ & $\underline{\underline{0.62}}$ & -0.07 & -0.01 & 0.00 \\
\hline & 4 主＼cjkstart婦 & 0.07 & 0.02 & -0.17 & 0.13 & -0.02 & 0.06 \\
\hline & 5 漁業者 & 0.00 & 0.00 & -0.43 & -1.08 & $\underline{\underline{0.88}}$ & -1.10 \\
\hline & 6 商＼cjkstart業 & $\underline{0.22}$ & $\underline{\underline{0.27}}$ & -0.10 & -0.29 & 0.33 & 0.16 \\
\hline & 7 学 生 & -0.64 & -0.51 & -0.80 & -0.09 & -0.48 & -0.23 \\
\hline & 8 観光 (遊船) & $\underline{0.56}$ & 0.93 & 0.10 & -0.09 & 0.47 & $\underline{0.41}$ \\
\hline & 9 その他 & 0.00 & -0.22 & -0.03 & -0.06 & -0.08 & -0.11 \\
\hline
\end{tabular}

注）二重下線は積極的評価、波線下線は消極的評価（それぞれスコアの絶対值が 0.2 以上）。

集落や年齢などの基礎情報アイテムのいずれが最も大きい 影響を与えているかを明らかにするため、数量化理論 I 類 分析を実施した(林知已夫著作集編集委員会編、2004)。

基礎情報アイテムの重要性は、数量化理論 I 類分析では レンジの大小によって順位付けを行った(表 5 参照)。

この結果、西の湖の将来シナリオ全体を通して、基礎情 報アイテムの「職業」がすべての将来シナリオについてレ ンジの大きさが 1 位であり、職業が将来シナリオ評価に与 えている影響が大きいと推測される。

そこで、職業とシナリオ評価の関係の詳細について、数 量化理論 I 類分析で得られているカテゴリースコアを職業 別にみることにした(表6参照)。
表 6 のカテゴリースコアが大きい順位で職業別に特徴を みると、次のようになる。

会社員は、高い評価または低い評価を与える、特定のシ ナリオは見当たらない。

公務員は、「魚のゆりかご」「伝統的農水産業」「環境 学習」に高い評価を与えている一方で、滞在型観光地」に は低い評価を与えている。

農業従事者は、「訪問型観光地」「滞在型観光地」を高く 評価するが、「魚のゆりかご」に対しては低く評価している。

主婦は、高い評価または低い評価を与える、特定のシナ リオは見当たらない。

漁業者は、「伝統的農水産業」を高く評価し、「滞在型観 
光地」「地域の公園」を低く評価している。

商業従事者は、「滞在型観光地」「訪問型観光地」「伝 統的農水産業」を高く評価する一方で、「地域の公園」を低 く評価している。

学生は5つのほとんどのシナリオに低い評価を与えている。

観光業従事者は、「魚のゆりかご」、「訪問型観光地」「伝 統的農水産業」「環境学習」に高い評価を与えている。

以上のように、職業別に西の湖の将来シナリオを見ると、 職業という立場で高く評価をするシナリオの違いがよく現 われているといえる。

\section{4 分析結果の考察}

以上のフォーカス・グループ・インタビューおよびアン ケート両調査の分析結果を通じて得られた成果は、以下の ようにまとめることができる。

まず、西の湖の将来シナリオに対する意見の違いは、因 子分析の結果、「伝統回帰環境志向」「観光地志向」、地 元公園志向」の 3 つの軸に集約できることが明らかになっ た。これらの 3 軸は、回答者の属性としての職業に起因し ているところが大きい。

また、内湖社会圈で暮らす地域住民の多数が、提示した 6 種類の将来シナリオの中でも、将来シナリオ「魚のゆり かごとしての西の湖」を支持していた。換言すれば、この 将来シナリオは回答者にとって包括的・中立的なイメージ を有していた。したがって、「魚のゆりかごとしての西の湖」 シナリオから出発し、具体的ビジョンを反映できる合意形 成に進むことができると考えられる。この点に関連して、 地域住民にとって象徴あるいはアイデンティティとなる動 植物が、自然保全への動機づけとなることは先行研究でも 指摘されているところである(長谷川、2008)。

\section{VI 結論と今後の課題}

本研究は、琵琶湖に残存する希少な内湖である西の湖を 対象として、ここで定義した内湖社会圈の中でも比較的意 欲の高い地区の地域住民の自然再生に対する意識構造を 探った。そのため、地域住民を対象とするフォーカス・グ ループ・インタビューならびにアンケート調査を行った結 果、西の湖の将来シナリオに対する評価は、回答者の職業 と相関を有していること等が明らかになった。

また、自然再生事業を対象とした先行研究において地域 住民間の意見の違いが質的な評価にとどまっているのに対 して、本研究では地域住民間の意見の違いを定量的に把握 することができた。

さらに、本研究では、職業と西の湖の将来シナリオ評価と の関連性が確認された。この点は、新藤(2007)が釧路湿原再 生において見出した、地域住民の労働と生活が主体間の関係 を規定するという事実とも対応しており、本研究は、地域住 民の意識構造に関する研究の実証性を一層高めたといえる。
一方、本研究の課題としては、内湖社会圈の地域住民内 の意見の調查研究であり、内湖社会圈と直接・間接に関わ りのある行政、NPO、研究者などの意見の聞き取りや収 集が含まれていないことが挙げられる。自然再生推進の持 続性を支えるうえで、共通の利害をもつステークホルダー からなる複数グループの形成と役割分担を、またステーク ホルダー間の相互交流を図る必要性を考慮するならば、多 様なステークホルダーの参加の下での合意形成システムを モデル化し、汎用性を持たせることが第一の課題に挙げら れる。

また、西の湖の将来シナリオの設定に関わる課題として は、生態系再生のシナリオとして、具体的な水質の改善程 度や生物相の目標が設けられていないことが挙げられる。 多様なステークホルダーの参加を前提とするならば、シナ リオ設定にあたって、理解しやすい表現、分かりやすい図 表や写真の使用などを含む、創意工夫を要するといえる。

本研究において、将来シナリオ評価を説明するモデル (表 5 参照) における決定係数は 0.10 に近く、比較的低い。説 明変数の追加などのモデルの改善、変数の測定方法の改善 が今後の研究課題として挙げられる。

さらに、フォーカス・グループ・インタビューの過程で、 地域の祭りなどの行事や、都市住民を引き付けるボラン ティア・イベントが、集落の凝集力・外部との連携につな がり、自然保全への動機づけとなることが指摘されている。 そうしたソーシャル・キャピタル要因の影響の確認も今後 の研究課題である。

\section{注}

1 ) 全設問のうち、設問の一部に無回答のあるアンケート・ データについては、集計・分析の有効度を高めるため、 適用した分析手法に応じて可能な限り算入することにし た。その結果、各回答、各分析で無効回答の数が異なる。

2 ) 平成 22 年国勢調查小地域集計によると、当該 3 町丁の 20 歳以上人口に占める、60歳以上人口の比率は約 $44 \%$ であ る。また、 3 町丁の全人口に対する 60 歳以上人口の占め る比率は、約 $35 \%$ である。

\section{謝辞}

現地での調査の実施にあたり、西の湖・内湖社会圈、近 江八幡市の方がたには情報提供について、また、井原有理、 梅原久奈、山元周吾の各氏には調査やデー夕整理の補助と して、多大な協力を得た。ここに謝意を表す。ただし、本 稿の内容については著者全員に責任がある。

本研究は、公益財団法人・住友財団により採択された「琵 琶湖内湖の自然再生を活性化するための管理統合に関する 環境政策研究」(2009年度・環境研究助成093473、研究代 表者: 竹下賢 - 関西大学法科大学院・教授) の研究助成に より実施したものである。 


\section{参考文献}

阿波根あずさ，中山徹 (2005) 計画策定段階からの地域参加に よる自然環境再生に関する研究, 日本建築学会大会学術 講演梗概集 (近畿) 2005 年 9 月, 957-958.

伊尾木慶子, 阿波根あずさ, 中山徹 (2006) 里山の自然再生・ 管理活動と地域住民の参加意識に関する研究——吹田市紫 金山公園を事例として, 平成 18 年度日本建築学会近畿支 部研究報告集, 6006, 313-316.

井上真 (2008) コモンズ論の遺産と展開, 井上真編, コモンズ 論の挑戦——新たな資源管理を求めて, 新曜社, 197-215. 宇沢弘文, 茂木愛一郎編 (1994) 社会的共通資本一ーモンズ と都市, 東京大学出版会, 17-20.

近江八幡市(2011) 重要文化的景観に関すること,〈http:// www.city.omihachiman.shiga.jp/contents_detail. $\mathrm{php} ? \mathrm{co}=\mathrm{cat} \& \mathrm{frmId}=4869 \& \mathrm{frmCd}=5-4-0-0-0\rangle, 2012$ 年 4 月 8 日アクセス.

奥野忠一, 久米均, 芳賀敏郎, 吉澤正 (1974) 多変量解析法, 日科技連出版社.

株式会社ラーゴ (2010) 西の湖 〜人と自然が織り成す生物多 様性〜，財団法人ハートランド推進財団，〈http://www. ramsar.org/pdf/Nishinoko_Leaflet.pdf〉, 2012年4月 8 日 アクセス.

環境省 (2012) 自然再生推進法に基づく自然再生事業の進渉状 況の公表について(平成24年3月30日), 〈http://www. env.go.jp/press/press.php?serial=15036〉 2012年5月 14 日アクセス.

高寛 (2009) 韓国における自然再生型まちづくりに関する NPO 及び専門家の意識調査——自然再生整備事業のイメージ と官民協働に関する事項を中心に, 都市住宅学, 67 号, 86-91.

柴有香, 桜井慎一(2005) 松浦川「アザメの瀬自然再生事業」に 対する住民意識の CVM 評価一一樫原湿原の保全事業との 比較を通じて, 日本建築学会大会学術講演梗概集 (近畿) 2005 年 9 月, $427-428$.

新藤慶 (2007) 自然再生をめぐるローカル・ガバナンスの論理 一一釧路湿原自然再生事業を事例として, 現代社会学研 究, 第 20 巻, $37-54$.
菅豊, 三俣学, 井上真 $(2010)$ グローバル時代のなかのローカ ル・コモンズ論, 三俣学, 菅豊, 井上真編, ローカル・コ モンズの可能性, ミネルヴァ書房, 1-9.

勢一智子 (2009) 協働型政策決定の法構造一自然再生推進法 を素材として, 西南学院大学法学論集, $41(3 \cdot 4), 197$ 238.

総務省 (2005) 平成 17 年国勢調査(小地域) 境界デー夕 (地図で見 る統計(統計 G I S ) ーデータダウンロード), 〈http://www. e-stat.go.jp/SG 2/toukeichiri/TopFrame. do?fromPage $=$ init\&to Page $=$ download $\rangle, 2012$ 年 5 月 7 日 アクセス

総務省 (2012) 平成 22 年国勢調査 小地域集計 25 滋賀県, 〈http://www.e-stat.go.jp/SG1/estat/List. do? bid $=000001036541 \&$ cycode $=0\rangle, 2012$ 年 1 月 17 日公表, 2012 年 5 月 7 日アクセス.

高塚敏, 進士五十八(2009)「田園自然再生活動コンクール」応 募票にみる農村地域における自然再生活動の俯瞰的現状, ランドスケープ研究：日本造園学会誌, 72 (5), 942-947.

高塚敏, 西塚賢二, 進士五十八 (2009) 田園自然再生活動の優 良事例にみる活動の拡大・発展要因と課題(技術報告編), 造園技術報告集, (5), 68-71.

高橋猛生 (2007) 政策形成過程における合意形成の困難性を生 み出す要因とは何か一三番瀬の自然再生を事例として, 法政大学大学院紀要, (59), 101-125.

千葉昭彦 (2007) 釧路湿原自然再生事業の展開過程——特にそ の合意形成過程に注目して, 季刊地理学, 59 (1), 31.

則久雅司 (2003) 行政資料 自然再生推進法の成立と施行につ いて, ランドスケープ研究, 66 (3), 250-251.

長谷川公一(2008) 自然再生プロジェクトと地域づくり—環 境社会学の視点から, 環境と公害, 38 (2), 23-29.

林知已夫著作集編集委員会編 (2004) 質を測る 数量化理論, 林知已夫著作集 3 , 勉誠出版.

文化庁 (2012) 重要文化的景観(平成24年1月24日現在), 〈http:// www.bunka.go.jp/bunkazai/shoukai/keikan/bukken. $h t m l\rangle, 2013$ 年 4 月 18 日アクセス.

ラムサール条約登録湿地関係市町村会議(2012) 日本のラム サール条約登録湿地[琵琶湖】,〈http://www.ramsarsite. jp/jp_11.html〉, 2012年4月8日アクセス. 